\title{
Perilaku Pengelolaan Keuangan Keluarga: Peran Moderasi Pendapatan
}

\section{Family Financial Management Behavior: The Moderating Role of Income}

\author{
Nur Af'idatul Husna ${ }^{1)}$, Lutfi Lutfi ${ }^{2)}$ \\ ${ }^{1,2)}$ Fakultas Ekonomi dan Bisnis, Universitas Hayam Wuruk Perbanas Surabaya, Kota Surabaya \\ e-mail korespondensi: lutfi@perbanas.ac.id
}

\begin{tabular}{|c|c|}
\hline fo & \multirow{3}{*}{$\begin{array}{l}\text { Abstrak } \\
\text { Perilaku manajemen keuangan penting dalam rangka mencapai kehidupan di } \\
\text { masa depan yang sejahtera secara finansial. Tujuan penelitian ini adalah untuk } \\
\text { menguji pengaruh pengalaman keuangan dan pengetahuan keuangan terhadap } \\
\text { perilaku pengelolaan keuangan keluarga dengan pendapatan sebagai variabel } \\
\text { moderasi. Sampelnya adalah } 249 \text { responden yang menikah dengan penghasilan } \\
\text { minimal Rp. 5.000.000,- per bulan dan berdomisili di Surabaya. Data dianalisis } \\
\text { menggunakan Structural Equation Modeling. Hasil penelitian menunjukkan } \\
\text { terdapat pengaruh positif yang signifikan antara pengalaman keuangan dan } \\
\text { pengetahuan keuangan terhadap perilaku pengelolaan keuangan keluarga; tidak } \\
\text { ada pengaruh pendapatan terhadap perilaku pengelolaan keuangan keluarga; } \\
\text { serta pendapatan memperkuat pengaruh pengetahuan keuangan terhadap perilaku } \\
\text { pengelolaan keuangan keluarga. Studi ini merekomendasikan rumah tangga } \\
\text { untuk mengeluarkan lebih banyak uang untuk program dana pensiun dan } \\
\text { meningkatkan pengetahuan keuangannya, terutama tentang investasi dan kredit. } \\
\text { Kata Kunci: Perilaku Manajemen Keuangan, Pengalaman Keuangan, } \\
\text { Pengetahuan Keuangan, Pendapatan. }\end{array}$} \\
\hline 21 & \\
\hline & \\
\hline & \multirow{3}{*}{$\begin{array}{l}\text { Abstract } \\
\text { Financial Management Behavior is crucial to achieve future financial well- } \\
\text { being. The purpose of this research is to examine the influence of financial } \\
\text { experience and financial knowledge on family financial management behavior } \\
\text { with income as a moderating variable. The samples are } 249 \text { respondents who } \\
\text { are married with a minimum income of Rp. 5.000.000,- per month and live in } \\
\text { Surabaya. Data is analysed using Structural Equation Modeling. The results } \\
\text { indicate that there are significant positive influences of financial experience } \\
\text { and financial knowledge to family financial management behavior; there is no } \\
\text { influence of income to family financial management behavior; and, income } \\
\text { strengthens the influence of financial knowledge to family financial } \\
\text { management behavior. This study suggests households to spend more money for } \\
\text { pension fund programs and improve their financial knowledge, especially about } \\
\text { investment and credit. } \\
\text { Keywords: Financial Management Behavior, Financial Experience, Financial } \\
\text { Knowledge, Income. }\end{array}$} \\
\hline & \\
\hline & \\
\hline
\end{tabular}




\section{PENDAHULUAN}

Setiap orang akan menginginkan hidup yang sejahtera secara finansial. Untuk mencapai tujuan kesejahteraan finansial ini maka seseorang perlu merencanakan dan mengelola keuangannya dengan baik. Perencanaan keuangan tidak hanya untuk kebutuhan jangka pendek, namun juga untuk jangka panjang. Pemasalahan yang terjadi pada masyarakat Indonesia adalah adanya kecenderungan untuk membuat perencanaan jangka pendek, yaitu memenuhi kebutuhan rutin bulanannya (OJK-RI, 2017). Ketika seseorang hanya terfokus pada perencanaan keuangan jangka pendek maka kebutuhan keuangan jangka panjang, seperti investasi, asuransi, dan dana pensiun, sering terabaikan. Agar seseorang mampu mencapai tujuan keuangan jangka panjangnya maka perlu dibarengi dengan pengelolaan keuangan yang baik pula.

Perilaku pengelolaan keuangan terkait pengelolaan pendapatan serta pengeluaran sedemikian rupa agar pendapatan yang dimiliki mampu memenuhi kebutuhan rutin dan masih memiliki kelebihan dana untuk tujuan jangka panjang (Hilgert et al., 2003). Dengan demikian, perilaku pengelolaan keuangan berkaitan dengan perencanaan, pengaturan, pelaksanaan, dan pengendalian keuangan untuk kebutuhan saat ini dan masa datang (Kholilah \& Iramani, 2013). Oleh karena itu, kajian mengenai penentu perilaku keuangan sangat penting untuk dilakukan agar dapat diidentifikasi sejak dini berbagai faktor yang mendorong ataupun menghambat tumbulnya perilaku keuangan yang baik.

Salah satu faktor penting penentu dari perilaku keuangan yang bijaksana adalah pengalaman keuangan (Hilgert et al., 2003). Pengalaman keuangan berkaitan dengan sejauh mana seseorang pernah memanfaatkan atau memiliki produk atau jasa keuangan dalam kehidupannya. Pengalaman yang lebih banyak dalam memanfaatkan produk-produk keuangan memberikan wawasan yang lebih baik mengenai keuntungan dan risiko suatu produk, sehingga hal ini mendorong perilaku pengelolaan keuangan yang lebih baik (Ameliawati \& Setiyani, 2018; Iramani \& Lutfi, 2021; Lusardi \& Tufano, 2015).

Keberhasilan dalam mengelola pola keuangan dengan baik tidak bisa terlepas dari pengetahuan keuangan (Lusardi \& Mitchell, 2014). Pengetahuan keuangan merupakan modal penting dalam membentuk perilaku keuangan yang baik (Huston, 2010). Pengetahuan keuangan yang lebih baik akan membawa kepada perilaku pengelolaan keuangan yang lebih bijak (Grohmann, 2018; Purniawati \& Lutfi, 2017).

Faktor penting lainnya sebagai penentu perilaku pengelolaan keuangan adalah pendapatan (Brilianti \& Lutfi, 2020; Perry \& Morris, 2005). Pendapatan yang tinggi akan memungkinkan seseorang memiliki kelebihan dana yang bisa ditabung atau diinvestasikan untuk kebutuhan masa depan (Arifin et al., 2017; Henager \& Mauldin, 2015; Servon \& Kaestner, 2008).

Selain memiliki pengaruh langsung, pendapatan juga bisa memoderasi pengaruh pengetahuan keuangan terhadap perilaku pengelolaan keuangan. Faktor pengetahuan keuangan yang baik belum tentu bisa menyebabkan perilaku pengelolaan yang baik jika tidak dibarengi dengan pendapatan yang memadai. Perilaku menabung, berinvestasi, serta menyisihkan dana untuk asuransi dan dana pensiun dapat lebih mudah dilakukan ketika seseorang memiliki kelebihan dana setelah memenuhi kebutuhan rutin. Dengan demikian, pendapatan dapat memperkuat pengaruh pengetahuan keuangan terhadap perilaku pengelolaam keuangan. Keberadaan pendapatan sebagai variabel moderasi inilah yang merupakan keterbaruan dari penelitian ini yang membedakannya dengan penelitian 
sebelumnya, seperti Arifin et al. (2017), Brilianti \& Lutfi (2020), serta Henager \& Mauldin (2015).

Pengelolaan keuangan keluarga dapat dikatakan lebih rumit daripada pengelolaan keuangan pribadi karena hal ini seringkali perlu seluruh anggota keluarga dengan beragam kebutuhan dan keinginan (Henager \& Mauldin, 2015). Hal ini yang mendorong peneliti untuk mengkaji perilaku pengelolaan keuangan keluarga.

Penelitian ini memiliki tujuan mengkaji perilaku pengelolaan keuangan keluarga di Kota Surabaya dengan pertimbangan bahwa Surabaya adalah kota metropolitan dengan Upah Minimum Kota (UMK) tertinggi di Jawa Timur (Kompas.com, 2019). Kehidupan keluarga di kota metropolitan sangat menarik untuk dikaji karena banyak dikelilingi oleh tempat hiburan dan belanja yang dapat mendorong perilaku konsumtif dan gaya hidup hedonis.

\section{Perilaku Pengelolaan Keuangan}

Perilaku pengelolaan keuangan atau financial management behavior berkaitan dengan kebiasaan seseorang untuk melakukan perencanaan dan pengendalian pengeluaran keuangan (Perry \& Morris, 2005). Aktivitas di dalam perilaku pengelolaan keuangan meliputi perencanaan, penganggaran, pemeriksaan, pengelolaan, pengendalian, pencarian dan penyimpanan keuangan seharihari (Kholilah \& Iramani, 2013). Secara umum, pengelolaan keuangan berkaitan dengan pengelolaan pendapatan, pengeluaran, pinjaman, tabungan, dan proteksi (Brilianti \& Lutfi, 2020). Dengan demikian, perilaku pengelolaan keuangan berkaitan dengan pengelolaan pendapatan dan penggunaan dari pendapatan itu untuk memenuhi kebutuhan konsumsi hari ini dan menyisihkan untuk kebutuhan masa datang.
Hilgert et al. (2003) menyatakan bahwa perilaku pengelolaan keuangan seseorang diukur dengan empat hal. Pertama adalah manajemen kas, yang meliputi kepemilikan rekening giro, pembayaran tagihan tepat waktu, penyusunan anggaran, serta pencatatan pengeluaran. Kedua yaitu manajemen kredit, yang meliputi kepemilikan kartu kredit, pembayaran tagihan kredit secara penuh, dan peninjauan laporan kredit. Ketiga adalah tabungan, meliputi kepemilikan akun bank, dana darurat, asuransi, penyisihan uang dari pendapatan yang diperoleh, tabungan untuk tujuan jangka panjang, serta kepemilikan sertifikat deposito. Keempat yaitu investasi, meliputi diversifikasi investasi, kepemilikan akun investasi (termasuk reksadana, saham, dan obligasi), serta perencanaan dana pensiun.

\section{Pengalaman Keuangan dan Perilaku Pengelolaan Keuangan}

Pengalaman keuangan (financial experience) adalah kejadian yang pernah dialami seseorang dalam kaitannya dengan kegiatan mengelola keuangan (Ameliawati \& Setiyani, 2018). Seseorang dapat memperoleh pengalaman keuangan secara pribadi, dari teman, atau kerabat. Pengalaman keuangan ini dapat membantu seseorang untuk mengelola keuangannya dengan lebih baik (Brilianti \& Lutfi, 2020). Pengalaman keuangan dapat diukur berdasarkan beberapa indikator, yaitu pengalaman perbankan, pasar modal, produk pegadaian, produk asuransi, produk dana pensiun, serta produk lembaga keuangan lainnya (Purwidianti \& Mudjiyanti (2016).

Semakin banyak pengalaman keuangan yang dimiliki seseorang maka semakin baik pula perilaku dalam mengelola keuangannya karena orang tersebut akan lebih memahami manfaat dan risiko suatu produk keuangan (Ameliawati \& Setiyani, 2018). Pengalaman keuangan merupakan salah satu bahan pertimbangan yang bisa digunakan seseorang 
ketika membuat suatu keputusan keuangan. Seseorang yang memiliki banyak pengalaman dalam menabung dan berinvestasi akan lebih mengetahui manfaatnya sehingga orang itu akan lebih berupaya dalam menyisihkan pendapatannya untuk ditabung ataupun diinvestasikan guna kebutuhan masa depan atau hari tua. Dengan demikian, semakin banyak pengalaman keuangan yang dimiliki maka seseorang dapat memperbaiki kondisi keuangan keluarganya di masa akan datang.

Perilaku keuangan yang didasari dengan pengalaman keuangan yang baik dan benar akan menciptakan pengelolaan pengeluaran keuangan keluarga yang teratur dan bijak (Brilianti \& Lutfi, 2020). Hal ini sejalan dengan penelitian Purwidianti \& Mudjiyanti (2016) yang menyatakan bahwa pengalaman keuangan berpengaruh positif dan signifikan terhadap perilaku keuangan keluarga.

\section{H1: Pengalaman keuangan berpengaruh positif terhadap perilaku pengelolaan keuangan keluarga.}

\section{Pengetahuan Keuangan dan Perilaku Pengelolaan Keuangan}

Pengetahuan keuangan adalah elemen dari modal manusia yang digunakan dalam aktivitas pengelolaan keuangan (Huston, 2010). Organization for Economic Cooperation and Development atau OECD (2016) memberi definisi literasi keuangan sebagai pengetahuan, pemahaman, maupun keterampilan konsep keuangan yang diperlukan untuk membuat keputusan keuangan yang efektif dalam meningkatkan kesejahteraan hidup (OJK-RI, 2017). Dengan demikian, manfaat utama dari pengetahuan keuangan adalah terwujudnya perilaku keuangan yang baik dan kondisi keuangan lebih sejahtera.

Pengetahuan keuangan dapat diukur dengan menggunakan beberapa indikator, yang mencakup pengetahuan tentang bunga dan kredit, pengetahuan tentang dividen, pengetahuan tentang penyusunan anggaran keuangan, pengetahuan mengenai prosedur membuka polis asuransi, pengetahuan tentang proses investasi pada reksadana, pengetahuan tentang tahapan investasi pada deposito, pengetahuan tentang cara investasi pada properti, serta pengetahuan tentang perincian laporan kredit (Kholilah \& Iramani, 2013).

Pengetahuan keuangan berkaitan erat dengan perilaku pengelolaan keuangan. Seorang individu yang memiliki lebih banyak pengetahuan tentang keuangan mampu mengelola keuangan dengan lebih baik serta cenderung terlibat dalam perilaku keuangan, seperti membayar semua tagihan tepat waktu, merekonsiliasi buku cek setiap bulan, dan memiliki dana darurat. Pengetahuan keuangan membuat seseorang lebih mampu menentukan keputusan yang baik untuk keluarga mereka dan memiliki keamanan finansial serta kesejahteraan ekonomi (Hilgert et al., 2003).

Seseorang yang memiliki pengetahuan keuangan yang baik akan lebih memikirkan masa depannya. Orang tersebut tidak akan menghabiskan pendapatannya hanya untuk kebutuhan saat ini, namun yang bersangkutan akan menyisihkan sebagian pendapatannnya untuk tabungan dan investasi demi masa depan ataupun asuransi guna berjaga-jaga terhadap berbagai risiko yang bisa terjadi di masa datang (Brilianti \& Lutfi, 2020). Argumen ini juga didukung oleh hasil penelitian Lusardi \& Mitchell (2014), Perry \& Morris (2005), dan Purniawati \& Lutfi (2017) yang menyimpulkan bahwa pengetahuan keuangan berpengaruh positif dan signifikan terhadap perilaku pengelolaan keuangan.

H2: Pengetahuan keuangan berpengaruh positif terhadap perilaku pengelolaan keuangan keluarga. 


\section{Pendapatan dan Perilaku Pengelolaan Keuangan}

Pendapatan merupakan penghasilan seseorang atau keluarga yang terdiri dari pendapatan inti dan pendapatan lain-lain yang diterima secara berkala (Brilianti \& Lutfi, 2020; Kholilah \& Iramani, 2013). Pendapatan bisa antara lain berupa gaji, tunjangan, bonus, pendapatan hasil usaha, pendapatan sewa, pendapatan bunga atau hasil investasi, dan pendapatan lain. Dalam konteks keluarga, pendapatan adalah mencakup pendapatan yang dihasilkan seluruh anggota keluarga, yaitu suami, istri, dan anak.

Besarnya pendapatan akan menentukan sejauhmana suatu keluarga dapat menyisihkan sebagian dananya untuk kebutuhan masa depan. Brilianti \& Lutfi (2020) membuktikan terdapat perbedaan perilaku pengelolaan keluarga berdasarkan tingkat pendapatan keluarga. Keluarga dengan pendapatan lebih besar memiliki pola perilaku pengelolaan keuangan yang secara signifikan lebih baik dibanding keluarga dengan pendapatan yang lebih rendah. Prihartono \& Asandimitra (2018) menyatakan bahwa ketika seseorang memiliki pendapatan yang lebih tinggi maka orang tersebut cenderung dapat mengelola keuangan dengan bijak karena mampu mengalokasikan uang untuk kegiatan lainnya seperti pengeluaran untuk kebutuhan seharihari, biaya pendidikan, tabungan, mendaftar asuransi, dan berinvestasi sehingga mampu mengelola keuangan mereka dengan baik.

H3: Pendapatan memiliki pengaruh positif terhadap perilaku pengelolaan keuangan keluarga.

Pendapatan juga dapat memperkuat pengaruh pengetahuan keuangan terhadap perilaku pengelolaan keuangan. Seseorang yang memahami dan mengerti pentingnya literasi keuangan belum tentu dapat menerapkannya dalam kehidupan sehari-hari apabila tidak memiliki pendapatan yang memadai. Seseorang dengan pendapatan yang rendah kemungkinan menggunakan seluruh uang yang dimilikinya untuk memenuhi kebutuhan sehari-hari. Dengan kata lain, perilaku keuangan yang baik dapat diterapkan apabila seseorang memiliki pendapatan yang tinggi, yaitu adanya pendapatan yang masih tersisa setelah digunakan untuk kebutuhan pokok sehari-hari (Brilianti \& Lutfi, 2020; Purniawati \& Lutfi, 2017).

Hal serupa juga berlaku dalam aspek pembayaran utang. Keluarga dengan jumlah pendapatan yang tinggi akan lebih mampu untuk membayar tagihan secara tepat waktu karena memiliki dana yang tersisa sehingga ini akan menghindarkan diri beban bunga yang semakin besar serta terpuruk dalam hutang (Herispon, 2019).

H4: Pendapatan memperkuat pengaruh dari pengetahuan keuangan atas perilaku pengelolaan keuangan keluarga.

Berdasarkan uraian, kerangka pemikiran penelitian ini disajikan pada Gambar 1.

\section{METODE PENELITIAN}

Populasi penelitian ini adalah seluruh keluarga yang berdomisili di Kota Surabaya. Sampel responden dipilih secara purposive sampling berdasarkan kriteria tertentu sesuai tujuan penelitian, yaitu berdomisili di wilayah Kota Surabaya, sudah berkeluarga dan/atau memiliki tanggungan, dan berpendapatan perbulan minimal Rp. 5.000.000,-. Penelitian ini juga menggunakan teknik convenience sampling yaitu sampel dipilih karena dapat dijangkau dengan mudah (Sugiyono, 2009).

Data primer penelitian dikumpulkan menggunakan survei berupa kuesioner yang disusun dalam bentuk Google Form dan disebarkan online melalui media sosial seperti Whatsapp kepada responden, yaitu keluarga yang berdomisili di daerah Surabaya. 


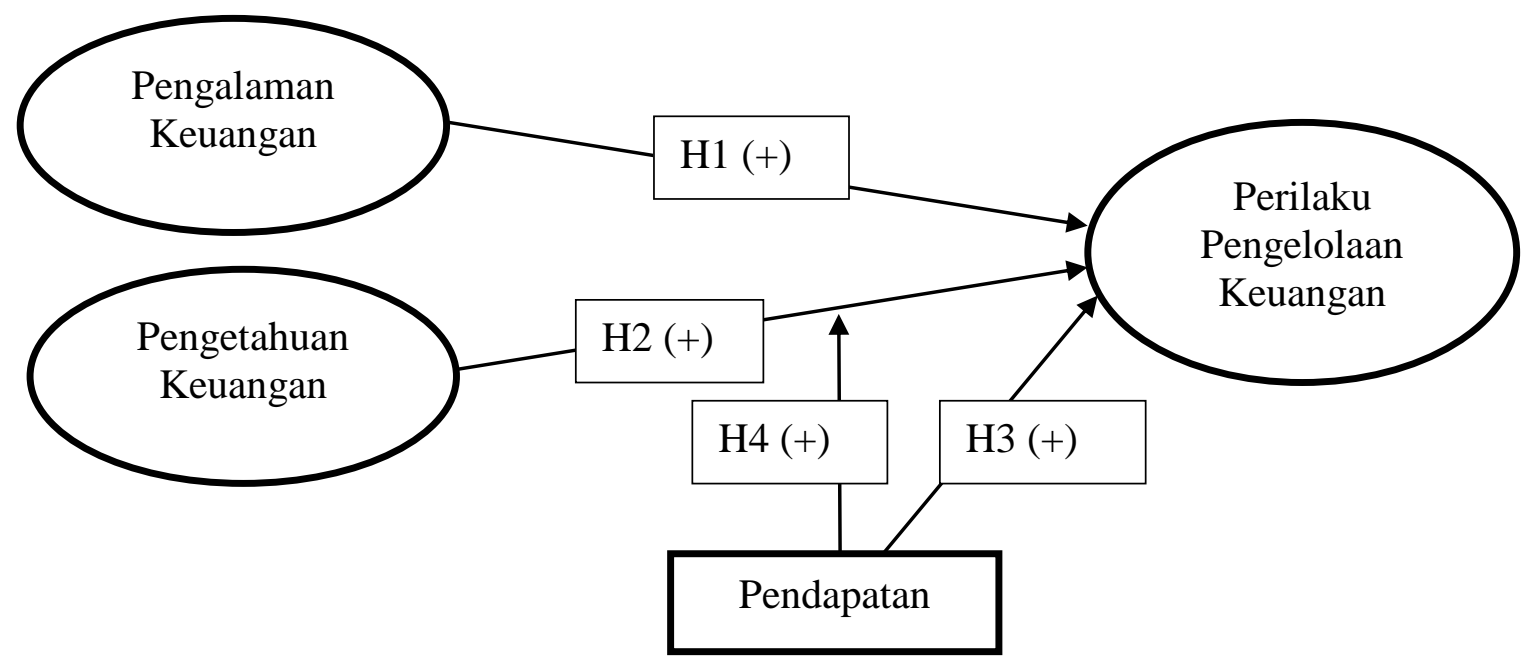

\section{Gambar 1. Kerangka Pemikiran}

Sumber: Diolah penulis, 2021.

Variabel dependen penelitian yaitu perilaku pengelolaan keuangan, variabel bebas berupa pengalaman keuangan dan pengetahuan keuangan, dan variabel moderasi adalah pendapatan. Perilaku pengelolaan keuangan adalah tindakan individu dalam mengelola keuangan sehari-hari. Hilgert et al. (2003) menyatakan bahwa indikator perilaku pengelolaan keuangan berupa pembayaran tagihan tepat waktu, pembayaran tagihan secara penuh, penyisihan uang untuk tabungan atau investasi, penyusunan rencana pengeluaran, penyusunan catatan pengeluaran, penyisihan uang untuk dana darurat, penyisihan uang untuk dana pension, dan penyisihan uang untuk asuransi. Perilaku pengelolaan keuangan dalam penelitian ini diukur menggunakan 5-skala Likert, yaitu: (1) Tidak Pernah, (2) Jarang, (3) Kadangkadang, (4) Sering, dan (5) Selalu.

Pengalaman keuangan adalah kejadian masa lalu yang berkaitan dengan keuangan dan dapat digunakan sebagai pertimbangan dalam pengelolaan keuangan. Purwidianti \& Mudjiyanti (2016) menyatakan indikator pengalaman keuangan berupa pengalaman terkait perbankan, program dana pension, produk asuransi, serta produk investasi.
Pengukuran variabel pengalaman keuangan dalam penelitian ini menggunakan skala Likert dengan skor 1 sampai 5, yaitu: (1) Tidak Pernah/Ada, (2) 1, (3) 2, (4) 3, dan (5) $>3$.

Pengetahuan keuangan adalah suatu kemampuan seseorang dalam memahami hal yang berkaitan dengan keuangan. Kholilah \& Iramani (2013) menyatakan bahwa indikator variabel pengetahuan keuangan meliputi pengetahuan umum keuangan, pengetahuan tentang tabungan, pengetahuan tentang kredit, pengetahuan mengenai asuransi, serta pengetahuan tentang investasi. Pengukuran variabel pengetahuan keuangan dalam penelitian ini menggunakan skala rasio.

Pendapatan adalah sejumlah uang yang diterima seseorang atau keluarga sebagai imbalan barang/jasa yang dihasilkan. Variabel ini diukur menggunakan skala interval dengan minimal pendapatan Rp. 5.000.000,- per bulan.

Teknik analisis data yang digunakan dalam penelitian ini adalah analisis deskriptif dan analisis inferensial dengan menggunakan metode Structural Equation Model-Partial Least Squares (SEM-PLS) dengan software SmartPLS 3. Tabel 1 menyajikan hasil uji 
validitas dan reliabilitas pada variabelvariabel perilaku pengelolaan keuangan keluarga dan pengalaman keuangan. Uji validitas digunakan untuk mengetahui derajat ketepatan penelitian yang dianggap telah sesuai dengan apa yang seharusnya diukur. Uji validitas menggunakan nilai loading factor dimana nilainya harus lebih besar dari 0,70 (Hair et al., 2017).

Sedangkan uji reliabilitas menjelaskan sejauhmana hasil pengukuran menggunakan instrumen itu dapat dipercaya. Uji reliabilitas menggunakan nilai composite reliability dan Cronbach's alpha dimana nilainya harus lebih besar dari 0,60 (Hair et al., 2017). Tabel 1 juga memperlihatkan semua indikator memilik loading faktor diatas 0,7 sehingga dengan demikian semua indikator adalah valid. Selanjutnya, nilai composite reliability dan Cronbach's alpha berada diatas 0,6 sehingga dapat disimpulkan bahwa semua konstruk adalah reliabel.

Selain itu, penelitian ini menggunakan Fornell-Larcker Criterion dan Heterotrait-
Monotrait ratio of Corelations (HTMT) untuk melakukan uji discriminant validity. Tabel 2 menunjukkan bahwa akar AVE dan nilai korelasi antara variabel dengan variabel itu sendiri (cetak tebal) lebih besar dibandingkan nilai AVE dan korelasi antara variabel tersebut dengan variabel yang lain. Karenanya, dapat disimpulkan bahwa discriminant validity untuk model penelitian ini sudah terpenuhi, dimana item pernyataan pada tiaptiap variabel sudah dapat mengukur variabel tersebut yang bebeda dari yang diukur variabel lain.

\section{HASIL ANALISIS}

Berdasarkan hasil penyebaran, terdapat 324 kuesioner yang telah diisi oleh responden melalui Google Form. Selanjutnya, seluruh kuesioner diseleksi sesuai dengan kriteria yang sampel penelitian dimana terdapat 75 yang tidak sesuai dengan kriteria, sehingga hanya 249 kuesioner yang dapat diolah dan diklasifikasikan atas dasar karakter demografi seperti disajikan pada Tabel 3.

Tabel 1. Uji Validitas dan Reliabilitas

\begin{tabular}{|c|c|c|c|c|c|}
\hline Variabel & Item & Pernyataan & $\begin{array}{l}\text { Loading } \\
\text { Factor }\end{array}$ & $\begin{array}{l}\text { Composite } \\
\text { Reliability }\end{array}$ & $\begin{array}{l}\text { Cronbach's } \\
\text { alpha }\end{array}$ \\
\hline \multirow{5}{*}{$\begin{array}{l}\text { Perilaku } \\
\text { Pengelolaan } \\
\text { Keuangan }\end{array}$} & FMB2 & $\begin{array}{l}\text { Menyisihkan pendapatan bulanan } \\
\text { untuk tabungan atau investasi }\end{array}$ & 0,764 & \multirow{5}{*}{0,897} & \multirow{5}{*}{0,858} \\
\hline & FMB3 & $\begin{array}{l}\text { Mematuhi anggaran atau rencana } \\
\text { pengeluaran yang sudah dibuat }\end{array}$ & 0,834 & & \\
\hline & FMB4 & $\begin{array}{l}\text { Menyisihkan dana untuk keadaan } \\
\text { darurat }\end{array}$ & 0,733 & & \\
\hline & FMB6 & $\begin{array}{l}\text { Menyisihkan uang untuk dana } \\
\text { pensiun mandiri }\end{array}$ & 0,865 & & \\
\hline & FMB7 & $\begin{array}{l}\text { Menyisihkan dana untuk } \\
\text { keikutsertaan asuransi mandiri }\end{array}$ & 0,788 & & \\
\hline \multirow{3}{*}{$\begin{array}{l}\text { Pengalaman } \\
\text { Keuangan }\end{array}$} & FE3 & $\begin{array}{l}\text { Jumlah program dana pensiun } \\
\text { mandiri yang saya miliki } \\
\text { sebanyak }\end{array}$ & 0,865 & \multirow{3}{*}{0,866} & \multirow{3}{*}{0,768} \\
\hline & FE4 & $\begin{array}{l}\text { Jumlah produk asuransi mandiri } \\
\text { yang saya miliki sebanyak }\end{array}$ & 0,830 & & \\
\hline & FE5 & $\begin{array}{l}\text { Jumlah produk investasi yang } \\
\text { saya miliki sebanyak }\end{array}$ & 0,784 & & \\
\hline
\end{tabular}

Sumber: Data primer diolah, 2021. 
Tabel 2. Discriminant Validity

\begin{tabular}{lcccccc}
\hline & \multicolumn{2}{c}{ PPK } & \multicolumn{2}{c}{ PLK } & \multicolumn{2}{c}{ PTK } \\
\cline { 2 - 6 } & FLC & HTMT & FLC & HTMT & FLC & HTMT \\
\hline Perilaku Pengelolaan Keuangan (PPK) & $\mathbf{0 , 7 9 8}$ & & & & & \\
Pengalaman Keuangan (PLK) & 0,491 & 0,582 & $\mathbf{0 , 8 2 7}$ & & & \\
Pengetahuan Keuangan (PTK) & 0,394 & 0,426 & 0,394 & 0,449 & $\mathbf{1 , 0 0 0}$ & \\
\hline
\end{tabular}

Sumber: Data primer diolah, 2021.

\section{Tabel 3. Karakteristik Responden}

\begin{tabular}{|c|c|c|c|}
\hline \multicolumn{2}{|c|}{ No. } & Jumlah Responden & Persentase \\
\hline \multicolumn{4}{|c|}{ Jumlah Tanggungan } \\
\hline 1 & $1-2$ & 140 & 56 \\
\hline 2 & $3-4$ & 87 & 35 \\
\hline 3 & $5-6$ & 19 & 8 \\
\hline 4 & $>6$ & 3 & 1 \\
\hline \multicolumn{4}{|c|}{ Status Perkawinan } \\
\hline 1 & Menikah & 192 & 77 \\
\hline 2 & Tidak Menikah & 57 & 23 \\
\hline \multicolumn{4}{|c|}{ Usia } \\
\hline 1 & 18 tahun -29 tahun & 50 & 20 \\
\hline 2 & Lebih dari 29 tahun - 39 tahun & 48 & 19 \\
\hline 3 & Lebih dari 39 tahun -49 tahun & 59 & 24 \\
\hline 4 & Lebih dari 49 tahun -59 tahun & 90 & 36 \\
\hline 5 & Lebih dari 59 tahun & 2 & 1 \\
\hline \multicolumn{4}{|c|}{ Total Pendapatan } \\
\hline 1 & Rp. 5.000.000,- - Rp. 7.500.000,- & 89 & 36 \\
\hline 2 & > Rp. 7.500.000,- - Rp. 10.000.000,- & 31 & 12 \\
\hline 3 & > Rp. 10.000.000,- - Rp. 12.500.000,- & 31 & 12 \\
\hline 4 & > Rp. 12.500.000,- - Rp. 15.000.000,- & 39 & 16 \\
\hline 5 & > Rp. 15.000.000,- & 59 & 24 \\
\hline
\end{tabular}

Sumber: Data primer diolah, 2021.

Tabel 3 menunjukkan bahwa sebagian besar responden memiliki jumlah tanggungan sebanyak 1 sampai 2 orang. Berdasarkan status perkawinan, sebagian besar responden sudah menikah. Berdasarkan usia, sebagian besar berusia 49 tahun sampai 59 tahun. Terakhir, berdasarkan total pendapatan per bulan, sebagian besar responden memiliki total pendapatan antara Rp. 5.000.000,sampai Rp. 7.500.000,-

\section{Statistik Deskriptif}

Tabel 4 menyajikan deskriptif statistik variabel penelitian. Tabel ini menunjukkan bahwa hasil tanggapan dari 249 responden pada variabel perilaku pengelolaan keuangan memiliki rata-rata sebesar 3,74 yang berarti responden memiliki perilaku pengelolaan keuangan keluarga yang baik. Variabel pengalaman keuangan memiliki rata-rata sebesar 2,37 yang berarti bahwa responden secara umum memiliki pengalaman keuangan 
yang rendah, atau rata-rata memiliki atau menggunakan kurang dari satu produk atau jasa keuangan. Sedangkan rata-rata untuk variabel pengetahuan keuangan sebesar 63 yang berarti bahwa responden secara umum memiliki pengetahuan keuangan yang cukup memadai (Chen \& Volpe, 1998).

\section{Hasil Pengujian}

Tabel 4 menyajikan hasil pengujian pengaruh langsung pengalaman keuangan terhadap perilaku pengelolaan keuangan dimana perolehan path coefficient sebesar 0,419 yang berarti memiliki pengaruh positif, dengan hasil $t$-hitung sebesar 6,719 dan nilai $p$-values sebesar 0,000. Hasil pengujian ini membuktikan bahwa hipotesis pertama $(\mathrm{H} 1)$ diterima karena $t$-hitung lebih dari 1,96 dan nilai $p$-values kurang dari 0,05 . Karenanya hasil penelitian ini membuktikan secara statistik bahwa pengalaman keuangan berpengaruh positif dan signifikan terhadap perilaku pengelolaan keuangan.

Berikutnya, Tabel 4 menunjukkan nilai perolehan path coefficient atas pengaruh langsung pengetahuan keuangan terhadap perilaku pengelolaan keuangan sebesar 0,145 dengan $t$-hitung sebesar 2,151 dan $p$-values sebesar 0,032. Hasil pengujian ini membuktikan bahwa hipotesis kedua (H2) diterima karena $t$-hitung lebih dari 1,96 dan nilai $p$ values kurang dari 0,05. Karenanya terbukti secara statistik bahwa pengetahuan keuangan berpengaruh positif dan signifikan terhadap perilaku pengelolaan keuangan.
Hasil ketiga dalam Tabel 4 menyatakan pengaruh langsung dari pendapatan terhadap perilaku pengelolaan keuangan memperoleh path coefficient sebesar 0,126 dengan hasil $t$-hitung sebesar 1,947 dan $p$-values sebesar 0,052 . Hasil pengujian ini menyatakan hipotesis ketiga (H3) ditolak karena $t$-hitung kurang dari 1,96 dan $p$-values lebih dari 0,05. Karenanya hasil penelitian ini membuktikan pendapatan secara statistik tidak berpengaruh signifikan pada perilau pengelolaan keuangan.

Terakhir, hasil pengujian dalam Tabel 4 berkenaan dengan peran moderasi pendapatan diperoleh nilai path coefficient sebesar -0,253 dengan hasil $t$-hitung sebesar 3,636 dan nilai $p$-values sebesar 0,000. Hasil pengujian ini membuktikan bahwa hipotesis keempat (H4) diterima karena nilai $t$-hitung lebih dari 1,96 dan $p$-values kurang dari 0,05. Dengan demikian dapat dinyatakan bahwa pendapatan memiliki peran moderasi yang memperkuat pengaruh pengetahuan keuangan terhadap perilaku pengelolaan keuangan keluarga.

\section{Pembahasan}

Berdasarkan hasil-hasil penelitian yang diperoleh maka bisa teridentifikasi bahwa pengalaman keuangan serta pengetahuan keuangan memiliki pengaruh yang signifikan, tapi pendapatan tidak berpengaruh signifikan, pada perilaku pengelolaan keluarga keluarga. Namun demikian, peran moderasi pendapatan terbukti berpengaruh signifikan memperkuat hubungan antara pengetahuan keuangan dan perilaku pengeloaan keuangan keluarga.

Tabel 4. Hasil Pengujian Hipotesis

\begin{tabular}{ccccc}
\hline Keterangan & $\begin{array}{c}\text { Original } \\
\text { Sample }(\mathrm{O})\end{array}$ & $\begin{array}{c}\text { T-Statistics } \\
(\mid \mathrm{O} / \text { STDEV } \mid)\end{array}$ & P-Values & Kesimpulan \\
\hline $\mathrm{FE} \rightarrow$ FMB & 0,419 & 6,719 & 0,000 & Diterima \\
$\mathrm{FK} \rightarrow$ FMB & 0,145 & 2,151 & 0,032 & Diterima \\
$\mathrm{P} \rightarrow$ FMB & 0,126 & 1,947 & 0,052 & Ditolak \\
$\mathrm{PK} * \mathrm{P} \rightarrow$ FMB & 0,253 & 3,636 & 0,000 & Diterima \\
\hline $\mathrm{R}-$ Square & 0,300 & Model Lemah \\
\hline
\end{tabular}

Sumber: Data primer diolah, 2021. 
Hasil pengujian menunjukkan bahwa semakin banyak pengalaman keuangan maka perilaku pengelolaan keuangan keluarga akan semakin baik. Perilaku keuangan yang didasari dengan pengalaman keuangan yang baik dan benar akan menciptakan pengelolaan pengeluaran keuangan keluarga dengan lebih teratur dan bijak (Brilianti \& Lutfi, 2020). Seseorang yang memiliki banyak pengalaman di bidang keuangan mampu membedakan mana yang harus dilakukan dan mana yang tidak boleh dilakukan serta dapat memahami risiko apa yang akan terjadi (Ameliawati \& Setiyani, 2018). Seseorang yang memiliki lebih banyak pengalaman dalam program pensiun mandiri selain BPJS, dapat lebih memahami manfaat dari program pensiun itu sehingga orang yang bersangkutan melakukan pengelolaan keuangannya dengan lebih baik, seperti menyisihkan pendapatannya untuk tabungan, investasi, dan dana pensiun.

Demikian juga seseorang yang memiliki lebih banyak pengalaman tentang produk asuransi mandiri akan cenderung memahami manfaat dari program asuransi itu sehingga orang bersangkutan bisa menerapkan perilaku pengelolaan keuangan yang lebih baik, seperti meyisihkan pendapatannya untuk asuransi. Terakhir, seseorang yang memiliki lebih banyak pengalaman dalam investasi akan lebih mengetahui manfaat dari investasi tersebut sehingga orang yang bersangkutan mengelola keuangan keluarganya dengan lebih baik, seperti mematuhi anggaran atau rencana pengeluaran yang sudah dibuat agar dapat menyisihkan pendapatan bulanannya untuk investasi.

Hasil pengujian juga membuktikan bahwa semakin baik pengetahuan keuangan maka perilaku pengelolaan keuangan keluarga akan semakin baik. Pengetahuan keuangan membuat seseorang atau keluarga lebih mampu menentukan keputusan yang baik bagi keluarga mereka dan memiliki keamanan finansial serta kesejahteraan ekonomi (Hilgert et al., 2003). Brilianti \& Lutfi (2020) mengatakan bahwa seseorang yang memiliki pengetahuan keuangan yang baik akan bisa melakukan perencanaan masa depannya dengan lebih baik. Orang tersebut akan menyisihkan sebagian dari pendapatan untuk tabungan dan investasi guna memenuhi kebutuhan masa depan dan kesejahteraan di hari tuanya.

Seseorang yang memiliki pengetahuan yang lebih baik tentang tabungan maka akan melakukan pengelolaan keuangan keluarga dengan lebih baik, seperti menyisihkan pendapatannya untuk tabungan. Hal ini didasarkan kepada indikator pengetahuan tentang tabungan yang memiliki skor cukup tinggi dan didukung dengan indikator pada perilaku pengelolaan keuangan keluarga yang menunjukkan bahwa responden menyisihkan pendapatan untuk tabungan dengan baik. Seseorang yang memiliki pengetahuan yang lebih baik tentang kredit maka orang tersebut dapat mengelola keuangan keluarganya dengan lebih baik, seperti membayar tagihan tepat waktu dan secara penuh. Hal ini didasarkan kepada indikator pengetahuan tentang kelayakan kredit yang memiliki skor sangat tinggi dan didukung dengan indikator pada perilaku pengelolaan keuangan yang menunjukkan bahwa responden membayar tagihan tepat waktu dan secara penuh dengan sangat baik.

Demikian juga seseorang yang memiliki pengetahuan yang lebih baik tentang asuransi dan investasi maka orang tersebut dapat menerapkan pengelolaan keuangan keluarganya dengan lebih baik, seperti menyisihkan pendapatan bulanannya untuk asuransi mandiri dan investasi. Hal ini didasarkan pada indikator pengetahuan tentang asuransi yang memiliki skor cukup tinggi dan didukung dengan indikator pada perilaku pengelolaan keuangan yang menunjukkan responden 
menyisihkan pendapatannya untuk asuransi mandiri dengan cukup baik.

Penelitian ini membuktikan bahwa semakin tinggi pendapatan maka belum tentu perilaku pengelolaan keuangan keluarga akan semakin baik. Hasil penelitian ini sejalan dengan studi Kholilah \& Iramani (2013) serta Purwidianti \& Mudjiyanti (2016) yang menyatakan pendapatan tidak berpengaruh terhadap perilaku pengelolaan keuangan. Pendapatan yang dimiliki tidak menjamin seorang individu untuk menerapkan perilaku pengelolaan keuangan keluarga yang baik. Adanya hasil yang tidak berpengaruh pada penelitian ini dimungkinkan karena fakor jumlah tanggungan. Responden dalam penelitian ini rata-rata memiliki tanggungan sebanyak 1 sampai 2 orang. Menurut Joo \& Grable (2004), jumlah tanggungan memberi pengaruh atas pengelolaan keluarga. Dengan jumlah tanggungan yang banyak maka kemungkinan bahwa seseorang menggunakan sebagian besar pendapatan yang diperolehnya untuk kebutuhan rutin keluarga, sehingga belum mampu menyisihkan pendapatannya untuk keuangan di masa yang akan datang seperti investasi.

Terakhir, penelitian ini membuktikan bahwa pendapatan memperkuat pengaruh pengetahuan keuangan terhadap perilaku pengelolaan keuangan keluarga. Dengan tingkat pengetahuan keuangan tertentu, apabila seseorang memiliki pendapatan yang lebih besar maka akan memiliki perilaku pengelolaan keuangan keluarga lebih baik. Peran moderasi pendapatan yang memperkuat pengaruh pengetahuan keuangan terhadap perilaku pengelolaan keuangan keluarga memiliki arti bahwa pendapatan yang lebih tinggi dapat memungkinkan keluarga yang memiliki pengetahuan yang baik akan menerapkan pengetahuan tersebut dalam mengelola keuangan keluarga dengan baik. Hal ini karena keluarga ini memiliki sisa dana yang memadai setelah memenuhi berbagai kebutuhan pokok keluarga. Keluarga seperti ini dinilai mampu menyisihkan pendapatan yang dimilikinya untuk tabungan, investasi, asuransi dan dana pensiun.

Hasil penelitian ini secara keseluruhan memberi bukti bahwa pengalaman keuangan, pengetahuan keuangan, dan pendapatan, mampu mempengaruhi perilaku pengelolaan keuangan keluarga. Berdasarkan skor koefisien determinasi diperoleh bahwa model yang dihasilkan dalam penelitian ini termasuk kategori lemah. Dengan demikian, perlu telaah lebh jauh atas sejumlah variaabel bebas lainnya yang dinilai turut mempengaruhi perilaku pengelolaan keuangan keluarga, seperti financial socialization (Safitri \& Kartawinata, 2020), sikap keuangan (Ameliawati \& Setiyani, 2018), locus of control (Perry \& Morris, 2005), serta jumlah tanggungan (Joo \& Grable, 2004).

\section{SIMPULAN}

Berdasarkan hasil analisis yang telah dilakukan secara deskriptif dan inferensial maka hasil penelitian ini menunjukkan bahwa pengalaman keuangan serta pengetahuan keuangan berpengaruh positif signifikan atas perilaku pengelolaan keuangan keluarga. Karenanya dapat disimpulkan bahwa semakin tinggi pengalaman keuangan seseorang maka perilaku pengelolaan keuangan keluarganya semakin baik. Pendapatan tidak berpengaruh terhadap perilaku pengelolaan keuangan keluarga. Pendapatan memperlemah pengaruh pengetahuan keuangan terhadap perilaku pengelolaan keuangan keluarga. Juga dapat disimpulkan bahwa ketika seseorang memiliki pengetahuan keuangan lebih baik dan pendapatan yang lebih rendah maka perilaku pengelolaan keuangan keluarga lebih baik.

Keterbatasan pada penelitian ini adalah hasil penelitian tidak dapat digeneralisir untuk wilayah Jawa Timur dikarenakan penyebaran 
kuesioner hanya dilakukan pada wilayah Kota Surabaya, serta kemampuan model ini hanya dapat menjelaskan perilaku pengelolaan keuangan adalah relatif lemah.

Saran bagi pengelola keuangan keluarga sebaiknya lebih banyak mengikuti program dana pensiun dan lebih meningkatkan aspek pengetahuan keuangan terutama berkaitan dengan investasi dan kartu kredit. Bagi peneliti selanjutnya disarankan untuk memperluas wilayah penelitian dari berbagai kota sehingga dapat digeneralisir untuk wilayah Jawa Timur dan menambahkan variabel lain, seperti, sikap keuangan, locus of control, dan demografi (jumlah tanggungan). Penelitian ini juga menyarankan para pembuat kebijakan untuk memberi edukasi berkenaan dengan elemen pengetahuan keuangan bagi masyarakat di Surabaya agar masyarakat mampu mengelola keuangan keluarga dengan lebih baik. Pengetahuan keuangan yang perlu menjadi perhatian terutama terkait dengan perilaku pengelolaan investasi dan kartu kredit yang rendah.

\section{REFERENSI}

Ameliawati, M., \& Setiyani, R. (2018). The influence of financial attitude, financial socialization, and financial experience to financial management behavior with financial literacy as the mediation variable. KnE Social Sciences, 3(10), 811-832. doi: 10.18502/kss.v3i10.3174.

Arifin, A. Z., Kevin, K., \& Siswanto, H. P. (2017). The influence of financial knowledge, financial confidence, and income on financial behavior among the workforce in Jakarta. MIX: Jurnal Ilmiah Manajemen, 7(1), 37-47. Retrieved from https://publikasi.mercu buana.ac.id/index.php/Jurnal_Mix/articl e/view/1476l.

Brilianti, T. R., \& Lutfi, L. (2020). Pengaruh pendapatan, pengalaman keuangan dan pengetahuan keuangan terhadap perilaku keuangan keluarga di Kota
Madiun. Journal of Business and Banking, 9(2), 197-213. doi: 10.14414/ jbb.v9i2.1762.

Chen, H., \& Volpe, R. P. (1998). An analysis of personal financial literacy among college students. Financial Services Review, 7(2), 107-128. doi: 10.1016/ S1057-0810(99)80006-7.

Dzulfaroh, A. N. (2019). UMK Jawa Timur 2020 disahkan, tertinggi Rp 4,2 juta, terendah Rp 1,9 juta. Kompas.com. Edisi 22 November 2019. Retrieved from https://www.kompas.com/tren/ read/2019/11/22/101322065/umk-jawatimur-2020-disahkan-tertinggi-rp-42juta-terendah-rp-19-juta?page $=$ all .

Grohmann, A. (2018). Financial literacy and financial behavior: Evidence from the emerging Asian middle class. PacificBasin Finance Journal, 48(April), 129143. doi: 10.1016/j.pacfin.2018.01.007.

Hair, J. F., Hult, G. T. M., Ringle, C. M., \& Sarstedt, M. (2017). A primer on partial least squares structural equation modeling (PLS-SEM). In SAGE ( $2^{\text {nd }}$ ed.). doi: 10.15358/9783800653614.

Henager, R., \& Mauldin, T. (2015). Financial literacy: The relationship to saving behavior in low-to moderate-income households. Family and Consumer Sciences Research Journal, 44(1), 7387. doi: 10.1111/fcsr.12120.

Herispon, H. (2019). An empirical analysis of household debt behavior determinants. Economics and Finance in Indonesia, 65(2), 132-148. doi: 10.47291/efi. v65i2.627.

Hilgert, M. A., Hogarth, J. M., \& Beverly, S. G. (2003). Household financial management: The connection between knowledge and behavior. Federal Reserve Bulletin, 89(7), 309-322. Retrieved from http://www.federal reserve.gov/pubs/bulletin/2003/0703lea d.pdf.

Huston, S. J. (2010). Measuring financial literacy. Journal of Consumer Affairs, 44(2), 296-316. doi: 10.1111/j.17456606.2010.01170.x. 
Iramani, R., \& Lutfi, L. (2021). An integrated model of financial well-being: The role of financial behavior. Accounting, 7(3), 691-700. doi: 10.5267/j.ac.2020.12.007.

Joo, S. H., \& Grable, J. E. (2004). An exploratory framework of the determinants of financial satisfaction. Journal of Family and Economic Issues, 25(1), 25-50. doi: 10.1023/ B:JEEI.0000016722.37994.9f.

Kholilah, N. A., \& Iramani, R. (2013). Studi financial management behavior pada masyarakat Surabaya. Journal of Business and Banking, 3(1), 69-80. doi: 10.14414/jbb.v3i1.255.

Lusardi, A., \& Mitchell, O. S. (2014). The economic importance of financial literacy: Theory and evidence. Journal of Economic Literature, 52(1), 5-44. doi: 10.1257/jel.52.1.5.

Lusardi, A., \& Tufano, P. (2015). Debt literacy, financial experiences, and over-indebtedness. Journal of Pension Economics \& Finance, 14(4), 332-368. doi: $10.1017 / \mathrm{S} 1474747215000232$.

OJK-RI. (2017). Strategi nasional literasi keuangan indonesia (Revisit 2017). Otoritas Jasa Keuangan. Retrieved from https://www.ojk.go.id/id/berita-dankegiatan/publikasi/Pages/StrategiNasional-Literasi-Keuangan-Indonesia(Revisit-2017)-.aspx.

Perry, V. G., \& Morris, M. D. (2005). Who is in control? The role of self-perception, knowledge, and income in explaining consumer financial behavior. Journal of Consumer Affairs, 39(2), 299-313. doi: 10.1111/j.1745-6606.2005.00016.x.
Prihartono, M. R. D., \& Asandimitra, N. (2018). Analysis factors influencing financial management behaviour. International Journal of Academic Research in Business and Social Sciences, 8(8), 3018-326. doi: 10.6007/ IJARBSS/v8-i8/4471.

Purniawati, R. T., \& Lutfi, L. (2017). Literasi keuangan dan pengelolaan keuangan keluarga dalam perspektif budaya Jawa dan Bugis. Journal of Business \& Banking, 7(1), 31-46. doi: 10.14414/ jbb.v7i1.963.

Purwidianti, W., \& Mudjiyanti, R. (2016). Analisis pengaruh pengalaman keuangan dan tingkat pendapatan terhadap perilaku keuangan keluarga di Kecamatan Purwokerto Timur. Benefit: Jurnal Manajemen Dan Bisnis, 1(2), 141-148. doi: 10.23917/benefit.v1i2. 3257.

Safitri, A., \& Kartawinata, B. R. (2020). Pengaruh financial socialization dan financial experience terhadap financial management behavior (Studi pada wanita bekerja di Kota Bandung). Jurnal Ilmu Keuangan Dan Perbankan (JIKA), 9(2), 158-169. doi: 10.34010/ jika.v9i2.2987.

Servon, L. J., \& Kaestner, R. (2008). Consumer financial literacy and the impact of online banking on the financial behavior of lower-income bank customers. Journal of Consumer Affairs, 42(2), 271-305. doi: 10.1111/ j.1745-6606.2008.00108.x.

Sugiyono. (2009). Metode penelitian kuantitatif kualitatif dan $R \& D$. Alfabeta. 